\title{
Poverty in South Sumatra Province Is Viewed From Village Fund and Village Fund Allocation
}

\author{
Rita Martini ${ }^{1,{ }^{*}}$ Endah Widyastuti ${ }^{1}$ Sukmini Hartati $^{1}$ Zulkifli $^{1}$ Riana Mayasari ${ }^{1}$ \\ Mardhiah $^{1}$
}

${ }^{1}$ Accounting Department, Polytechnic State of Sriwijaya, Palembang 30139, Indonesia

${ }^{*}$ Corresponding author. Email: 1

\begin{abstract}
This study aims to analyze the effect of village funds and village fund allocations on poverty in South Sumatra Province. The sample used in this study was from 14 districts/cities in South Sumatra, selected based on the purposive sampling method. This study uses multiple regression data analysis. The results of this study indicate that the variable allocation of village funds has no effect on poverty. Meanwhile, village funds have a positive and significant effect on poverty. The research observation period was too short, and it is recommended to use more complete data with a longer study period. In addition, the variables used in further research are expected to be more complete and varied by adding other independent variables. It is hoped that the district/city government in South Sumatra Province can maximize the use of village fund allocations to achieve the goal of poverty alleviation in the district/city through the use of village spending.
\end{abstract}

Keywords: village financial governance, poverty.

\section{INTRODUCTION}

Poverty is the inability to meet a minimum standard of living in accordance with the standard of living. As an aggregate measure, the level of poverty in an area is used to measure the level of welfare in the region. Several factors cause poverty (Maipita, 2014) among them are low local and global economic growth, low level of education and mastery of technology, limited natural resources, high population growth, and unfavorable political stability.
The Province of South Sumatra is one of the provinces with the highest number of poor people on the island of Sumatra. The percentage of poverty in South Sumatra in 2018 was recorded at 1 million people or $12.82 \%$ of a total of 8 million people. This percentage is still higher than the national poverty rate of $9.66 \%$. The number and percentage of poor people by regency/city in South Sumatra Province in 2017 and 2018 are presented in table 1 .

Table 1 Number of Regency/City Poor Population in South Sumatra Province 2017-2018

\begin{tabular}{lcccc}
\hline \multirow{2}{*}{ Regency/City } & \multicolumn{2}{c}{ Number of Poor Population (thousands) } & $\begin{array}{c}\text { Percentage of Poor Population } \\
(\boldsymbol{\%})\end{array}$ \\
\cline { 2 - 5 } & $\mathbf{2 0 1 7}$ & $\mathbf{2 0 1 8}$ & $\mathbf{2 0 1 7}$ & $\mathbf{2 0 1 8}$ \\
\hline Ogan Komering Ulu & 46,336 & 45,771 & 12.95 & 12.61 \\
Ogan Komering Ilir & 127,063 & 124,856 & 15.75 & 15.28 \\
Muara Enim & 81,304 & 78,581 & 13.19 & 12.56 \\
Lahat & 67,327 & 65,310 & 16.81 & 16.15 \\
Musi Rawas & 55,958 & 54,746 & 14.24 & 13.76 \\
Musi Banyuasin & 105,083 & 105,149 & 16.75 & 16.52 \\
Banyuasin & 95,280 & 95,288 & 11.47 & 11.32 \\
OKU Selatan & 38,628 & 37,867 & 10.98 & 10.64 \\
OKU Timur & 72,809 & 70,648 & 11.00 & 10.57
\end{tabular}




\begin{tabular}{|c|c|c|c|c|}
\hline \multirow[t]{2}{*}{ Regency/City } & \multicolumn{2}{|c|}{ Number of Poor Population (thousands) } & \multicolumn{2}{|c|}{$\begin{array}{c}\text { Percentage of Poor Population } \\
(\%)\end{array}$} \\
\hline & 2017 & 2018 & 2017 & 2018 \\
\hline Ogan Ilir & 56,845 & 55,867 & 13.58 & 13.19 \\
\hline Empat Lawang & 30,294 & 30,199 & 12.44 & 12.25 \\
\hline PALI & 26,745 & 25,770 & 14.53 & 13.81 \\
\hline Musi Rawas Utara & 36,455 & 36,191 & 19.49 & 19.12 \\
\hline Palembang & 184,407 & 179,320 & 11.40 & 10.95 \\
\hline Prabumulih & 20,720 & 20,945 & 11.42 & 11.39 \\
\hline Pagar Alam & 12,120 & 12,069 & 8.89 & 8.77 \\
\hline Lubuk Linggau & 29,543 & 29,741 & 13.12 & 13.02 \\
\hline South Sumatra & $1,086,917$ & $1,068,267$ & 13.19 & 12.80 \\
\hline
\end{tabular}

Source: BPS Sumsel, 2020

From the above phenomena, a breakthrough is needed in reducing poverty in villages. Lin \& Prasetyanto (2012) stated that economic growth in China is supported by fiscal reforms accompanied by rural reforms. This research is also in accordance with the research conducted by Martowardojo (2012), that fiscal decentralization has significantly impacted catching-up for previously underdeveloped regions. Thus it can be concluded that rural development is a prerequisite for increasing economic growth that carries the concept of equity. Therefore, the implementation of village development will require adequate financing or sources of village revenue (Martini, et al, 2020).

The Central Statistics Agency (BPS) explains that the percentage of poverty in 2017 in cities reached $1.26 \%$ (percent) while the percentage of poverty in villages was $13.47 \%$ (percent), this shows that the poverty rate is still a lot in rural areas (BPS Republic of Indonesia, 2018). With the increase in the poverty rate, the government has implemented various policies to overcome this problem, such as the existence of a village fund program and the allocation of village funds.

The higher the village fund (DD) and village fund allocation (ADD) are expected to be able to reduce the poverty rate so that the poverty rate will decrease. Research (Goddess \& Rhythm, 2018), (Susilowati,
Susilowati, \& Hadi, 2017) and (Sari \& Abdullah, 2017) prove that DD and ADD have a significant effect on poverty. While research (Lalira, Nakoko, \& Rorong, 2018) prove that DD and ADD do not have a significant effect on poverty.

The difference in this study from previous studies is that the population used is all districts/cities in South Sumatra Province.

\section{LITERATURE REVIEW AND HYPOTHESIS DEVELOPMENT}

Permendagri No. 113 of 2014 states, village funds (DD) are a source of village funds originating from the state budget and expenditures transferred through the district/city regional revenue and expenditure budget and used to carry out governance, village development, guidance, and community empowerment. UU no. $6 / 2014$ states that the ADD is $10 \%$ of the balancing funds received by districts/cities in the APBD after deducting the special allocation funds. Poverty is a condition where a person cannot enjoy all kinds of choices and opportunities in fulfilling their basic needs, such as not being able to meet health, a decent standard of living, freedom, self-respect, and a sense of respect from others as well as the gloomy future of the nation and state (Wiguna \& Rachmad, 2013).

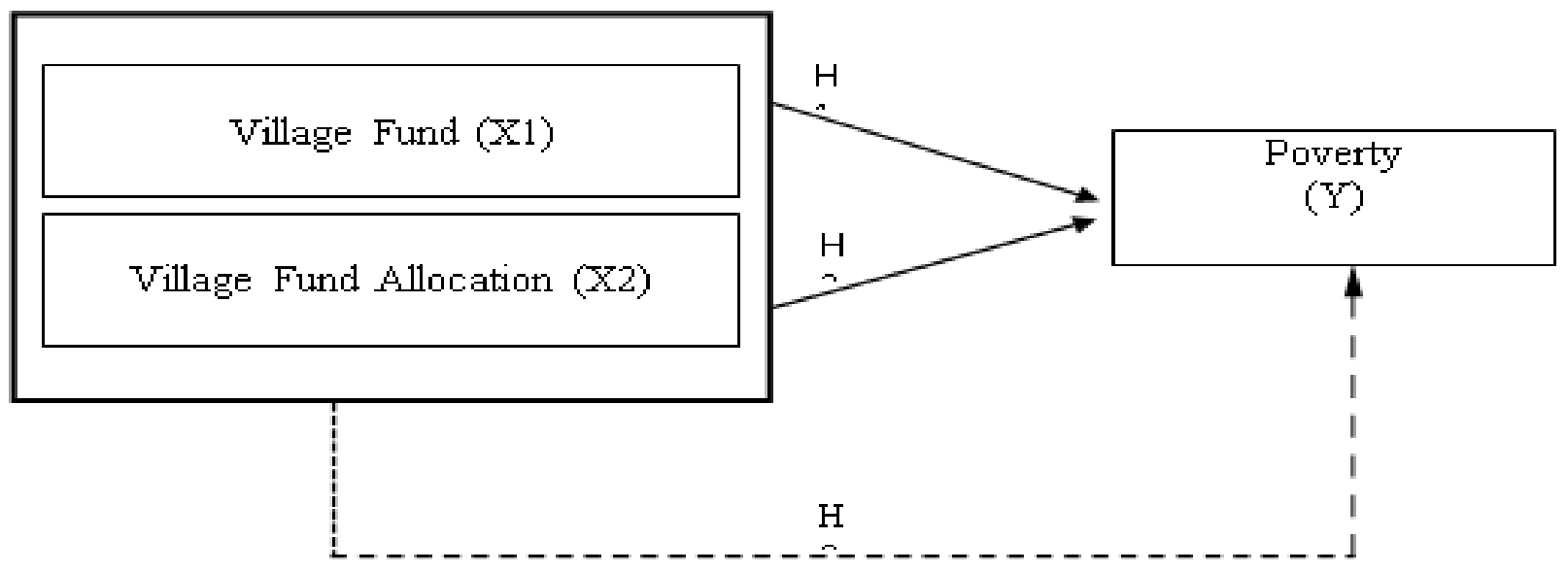

Source: Data processed (2020)

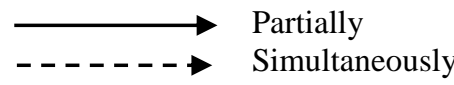

Figure 1 Research Framework 
Research Hypothesis:

H1: Village funds are influential significant impact on poverty.

H2: Allocation village funds are influential significant impact on poverty.

H3: Village funds and village fund allocations have a significant effect together or simultaneously on poverty.

\section{RESEARCH METHODOLOGY}

This type of research is a causal associative research with quantitative methods. The type of data used is quantitative data, which is in the form of numbers or numbers which are processed or analyzed using mathematical calculation techniques. The data source used in this research is secondary data. This secondary data consists of LRA APBDes which is obtained directly from DPMD and BPS.

The population in this study were all districts in South Sumatra Province which consisted of 17 regencies/cities.

The sampling technique used to determine the sample in this study was purposive sampling or taking members of the sample from the population with certain considerations. The sampling criteria are presented in Table 2.

Table 2. Research Sample Determination Criteria

\begin{tabular}{clc}
\hline No. & \multicolumn{1}{c}{ Criteria } & Amount \\
\hline 1 & $\begin{array}{l}\text { Regency/City in South Sumatra } \\
\text { Province }\end{array}$ & 17 \\
2 & $\begin{array}{l}\text { Districts/Cities that do not } \\
\text { receive DD and ADD }\end{array}$ & $(3)$ \\
2 & LRA APBDes which has DD and & 14
\end{tabular}

ADD components

\begin{tabular}{clc}
3 & Research year & 5 \\
\hline Total Unit of Analysis & 60 \\
\hline Source: Data processed (2020)
\end{tabular}

Based on the sampling calculation in Table 2, the number of districts in South Sumatra Province that can be sampled is 14 regencies. Table 3 presents a list of districts in South Sumatra Province that were sampled as well as units of analysis in this study.

Table 3. Research Samples

\begin{tabular}{cl}
\hline No. & \multicolumn{1}{c}{ Regency/City } \\
\hline 1 & Ogan Komering Ulu \\
2 & Ogan Komering Ilir \\
3 & Muara Enim \\
4 & Lahat \\
5 & Musi Rawas \\
6 & Musi Banyuasin \\
7 & Banyuasin \\
8 & OKU Selatan \\
9 & OKU Timur \\
10 & Ogan Ilir \\
11 & Empat Lawang \\
12 & PALI \\
13 & Musi Rawas Utara \\
14 & Prabumulih \\
\hline
\end{tabular}

Source: Data processed (2020)

There are 2 (two) independent variables and 1 (one) dependent variable as follows:

Dependent Variable: $\mathrm{Y}=$ Poverty

Independent Variable: $\mathrm{X} 1=$ Village Fund

$\mathrm{X} 2$ = Allocation of village funds

The operational definition of the variables in this study is presented in Table 4 .

Table 4. Variable Operations

\begin{tabular}{|c|c|c|c|}
\hline Variable & Definition & Data source & Scale \\
\hline \multicolumn{4}{|c|}{ Dependent Variable } \\
\hline $\begin{array}{l}\text { Poverty } \\
\text { (Y) }\end{array}$ & $\begin{array}{l}\text { A condition where a person cannot enjoy all kinds of choices and } \\
\text { opportunities in fulfilling their basic needs, such as not being able to meet } \\
\text { health, a decent standard of living, freedom, dignity, and a sense of } \\
\text { respect from others as well as the gloomy future of the nation and state. }\end{array}$ & $\begin{array}{l}\text { Central Bureau } \\
\text { of Statistics } \\
\text { (BPS) }\end{array}$ & Ratio \\
\hline \multicolumn{4}{|c|}{ Independent Variable } \\
\hline $\begin{array}{c}\text { Village } \\
\text { Fund (X1) }\end{array}$ & $\begin{array}{l}\text { APBN funds allocated for villages that are transferred through the district } \\
\text { / city APBD and prioritized for development implementation; and } \\
\text { empowerment of rural communities. }\end{array}$ & $\begin{array}{l}\text { LRA APBDes } \\
\text { from DPMD. }\end{array}$ & Ratio \\
\hline $\begin{array}{l}\text { Village } \\
\text { Fund } \\
\text { Allocation } \\
\quad(\mathrm{X} 2)\end{array}$ & $\begin{array}{l}\text { The allocation of funds to villages based on the calculation of the balance } \\
\text { funds originating from the district is } 10 \% \text { after deducting the special } \\
\text { allocation funds. }\end{array}$ & $\begin{array}{l}\text { LRA APBDes } \\
\text { from DPMD. }\end{array}$ & Ratio \\
\hline
\end{tabular}

Source: Data processed, 2020

Ghozali (2017, p.147), revealed descriptive statistics provide an overview or description of data seen from the mean, standard deviation, variance, maximum, minimum, sum, range, kurtosis, and Skewness (slope distribution). In this study, what is seen 
is the average (mean), standard deviation, maximum, and minimum values of the research data.

Furthermore, the classical assumption test is carried out, namely normality test, multicollinearity test autocorrelation test, and heteroscedasticity test.

Hypothesis testing is performed using multiple linear analysis models aimed at predicting the strength of the influence of the independent variable on the dependent variable.

The determination coefficient test $\left(\mathrm{R}^{2}\right.$ test) aims to measure the extent to which the independent variable can explain the variation of the dependent variable, either partially or simultaneously.

The F statistical test aims to determine whether together the independent variables have a significant effect on the dependent variable. This study uses the $\mathrm{F}$ statistical test by comparing $F_{\text {count }}$ and $F_{\text {table }}$ and seeing the probability value. If $\mathrm{F}_{\text {count }}>\mathrm{F}_{\text {table, }}$, then $\mathrm{H}_{\mathrm{a}}$ is accepted. If a probability value $<0.05$ then $\mathrm{H}_{\mathrm{a}}$ is accepted.

The $\mathrm{t}$ statistical test is used to test the hypothesis partially to show the effect of each independent variable individually on the dependent variable. This study uses the $t$ statistical test by comparing $t_{\text {count }}$ and $t_{\text {table }}$ and seeing the probability value. If $t_{\text {count }}>t_{\text {table }}$, then $\mathrm{Ha}$ is accepted. If a probability value $<0.05$ then $\mathrm{H}_{\mathrm{a}}$ is accepted.

\section{RESULT AND DISCUSSION}

\subsection{Result}

From the results of data collection regarding village funds, village fund allocation, and poverty in South Sumatra Province, descriptive statistics of research variables are obtained as in Table 5 .

Table 5. Descriptive Statistics Results

\begin{tabular}{l|r|r|r|r|r} 
& \multicolumn{1}{|c}{ Descriptive Statistics } & \multicolumn{1}{c}{ Mean } & \multicolumn{1}{c}{ Std. Deviation } \\
\hline Village Fund & 70 & 1670439 & 301179650 & 140087235.49 & 82893023,218 \\
\hline $\begin{array}{l}\text { Village Fund } \\
\text { Allocation }\end{array}$ & 69 & 2140000000 & 266676693200 & 74370973579.00 & 57091789586,494 \\
\hline Poverty & 70 & 20470 & 134070 & 61728.14 & 31317,825 \\
\hline Valid N (listwise) & 69 & & & & \\
\hline
\end{tabular}

Source: SPSS output, 2020

\subsubsection{Classic Assumption Test}

The normality test aims to test whether the regression model, the dependent variable and the independent variable both have a normal distribution or not (Ghozali I., 2017, p. 156). Based on the test results, it is concluded that the data has a normal distribution with a significant value of 0.080 which is greater than 0.05 , it can be stated that the data has a normal distribution.

This multicollinearity test aims to test whether the regression model found a correlation between independent or independent variables. This study uses a multicollinearity test by looking at the Tolerance and Variance Inflation Factor (VIF) values in the regression model. Multicollinearity test results shows that all independent variables have a tolerance value above 0.10 and a VIF value below 10, so it can be concluded that the regression model in this study does not occur multicollinearity.

The autocorrelation test was conducted to determine whether in the linear regression model there was a correlation between confounding error in period $t$ and with confounding error in period t-1 (previous). Based on the results of the Durbin Watson test, it was found that the DW value was between the dU and 4-dU values. So it can be concluded that there is no autocorrelation problem.

Heteroscedasticity test (Ghozali I., 2017 p.105)aims to test whether in the regression model there is an inequality of variants from the residuals of one observation to another (error value). Based on the results of the heteroscedasticity test, it can be seen that the dots do not form a clear pattern. The points spread above and below the 0 on the $\mathrm{Y}$ axis. So it can be concluded that there is no heteroscedasticity problem in the regression model.

\section{Multiple Linear Regression Results}

Multiple linear regression analysis aims to measure the influence of the independent variable on the dependent variable. Table 6 shows the test results of multiple linear regression analysis. 
Table 6. Multiple Linear Regression Analysis Test Results

\begin{tabular}{|c|c|c|c|c|c|c|}
\hline \multicolumn{7}{|c|}{ Coefficients } \\
\hline \multirow{2}{*}{\multicolumn{2}{|c|}{ Model }} & \multicolumn{2}{|c|}{ Unstandardized Coefficients } & \multirow{2}{*}{$\frac{\text { Standardized Coefficients }}{\text { Beta }}$} & \multirow[b]{2}{*}{$\mathrm{t}$} & \multirow[b]{2}{*}{ Sig. } \\
\hline & & $\mathrm{B}$ & Std. Error & & & \\
\hline \multirow[t]{3}{*}{1} & (Constant) & 27244.072 & 6210.545 & & 4.387 & .000 \\
\hline & Village Fund & .000 & .000 & .525 & 4.664 & .000 \\
\hline & Village Funds Allocation & $8.228 \mathrm{E}-8$ & .000 & .150 & 1.330 & .188 \\
\hline
\end{tabular}

a. Dependent Variable: Poverty

Source: SPSS output, 2020

Based on table 6 , the output of the results of multiple linear regression analysis, the regression equation is obtained as follows:

$$
\begin{aligned}
\text { Poverty }= & 27244.072+0,000 \text { Village Fund }+8.228 \\
& \text { Village Fund Allocation }+\mathrm{e}
\end{aligned}
$$

From the regression model above, it can be identified that the Village Fund and the Village Fund Allocation have a positive direction towards poverty. Then the regression is interpreted as follows:

1. The constant value (a) is equal to 27244.072 this means that the average poverty of the district/city will increase by 27244.072 assuming that the Village Fund and Village Fund Allocation do not change or are considered constant.

2. Village Fund variable with a coefficient value 0,000 meaning that if the Village Fund variable increases by one percent while other variables remain, it will result in an increase in the value of the Poverty variable by 0,000 .

3. Village Fund Allocation Variable with a coefficient value 8.228 this means that if the Village Fund Allocation variable increases by one percent while other variables remain, it will result in an increase in the value of the Poverty variable by 8.228 .

\subsubsection{Hypothesis Testing}

Based on the results of $t$ statistical test, it is known that the value $t_{\text {count }}$ of Village Fund variable of 4.664 with a significance of $0,000 \mathrm{t}_{\text {count }}>\mathrm{t}_{\text {table }}(4.664>$ $1.99656)$ and sig value $<0.05(0.000<0.05)$. So it can be concluded that the Village Fund partially affects Poverty. The value $t_{\text {count }}$ of Village Fund Allocation variable is 1.330 with a significance of 0.188 , then $t_{\text {count }}$ $<t_{\text {table }}(1.330<1.99656)$ and a sig $>0.05(0.188>0.05)$. So it can be concluded that partially the Village Fund Allocation has no effect on poverty.

The results of the $F$ statistical test, that $F_{\text {count }}$ is 19.938 and a significant value is 0.000 , while the $F_{\text {table }}$ value is 3.14 , then $F_{\text {count }}>F_{\text {table }}(19,938>3.14)$ and $\operatorname{sig} F$ $<0.05(0.000<0.005)$. So it can be concluded that simultaneously the independent variables, namely Village Fund (X1), and Village Fund Allocation $\left(\mathrm{X}_{2}\right)$ have a positive and significant effect on the dependent variable, namely Poverty (Y).

The results of the Adjusted R Square or the coefficient of determination are 0.377 . It can be interpreted that variable $\mathrm{X}$ has a contribution effect of $37.70 \%$ to variable Y. While the rest $62.30 \%$ is explained by other independent variables not included in this study.

\subsection{Discussion}

\subsubsection{The Influence of Village Funds on Poverty}

Based on the results of hypothesis testing, the tcount for Village Funds is 4.664. When compared with the $t_{\text {table }}$ value of 1.99656 , the $t$-count obtained is greater than the t-table value. In addition, the significance value of the Village Fund variable shows a value below the significant level of $5 \%(\alpha=0.05)$, which is 0.00 . So it can be concluded that the village fund has a positive and significant relationship or effect on poverty in districts/cities in South Sumatra Province in 2015-2019. This means that the first hypothesis in this study is accepted. Furthermore, based on the results of the analysis of the strength of the relationship between the dependent variable and the independent variable or analysis to find out how much the independent variable explains the dependent variable, it can be seen that the coefficient of determination $\mathrm{R}^{2}$ is 0.377 . This value means that $37.7 \%$ of the variable regarding poverty in regencies/cities in South Sumatra Province is influenced by Village Fund Allocation, while the rest is influenced by other variables.

The results of this study are in line with the purpose of providing village fund transfers, namely to improve the welfare of rural communities and the quality of life of rural communities as well as to reduce village poverty. This means that in practice the regensy/city governments in South Sumatra Province have achieved the objectives of the Village Fund. So it can be concluded that there is a relationship between the village fund and poverty, which if the village fund increases, it will affect the poverty level of the regency/city in South Sumatra Province.

This research is in line with Susilowati \& Hadi (2017) which states that Village Funds has an effect on poverty, meaning that the more optimalization of Village Funds will affect the level of poverty. Dari \& Abdullah (2017) stated that the Village Fund can explain village poverty in Tulung Agung Regency. In contrast to the research results of Lalira, et al. (2018), namely the Village Fund has no effect on the level of poverty in Gemeh District, Talaud Islands Regency. This is due to the use of different samples and time periods. 


\subsubsection{The Influence of Village Funds Allocation on Poverty}

Based on the results of hypothesis testing, the tcount for Village Fund Allocation is 1.330. When compared with the t-table value of 1.99656 , then the $\mathrm{t}$ count obtained is smaller than the t-table value. In addition, the significance value of the Village Fund Allocation variable shows a value above the significant level of $5 \%(\alpha=0.05)$, which is 0.188 . So it can be concluded that the Village Fund Allocation variable has no relationship or has no effect on poverty in districts/cities in South Sumatra Province in 2015-2019. This means that the second hypothesis in this study is rejected. Furthermore, based on the results of the analysis of the strength of the relationship between the dependent variable and the independent variable or analysis to find out how much the independent variable explains the dependent variable, It can be seen that the coefficient of determination $\mathrm{R}^{2}$ is 0.377 . This value means that $37.7 \%$ of the variable regarding poverty in regencies/cities in South Sumatra Province is influenced by Village Fund Allocation, while the rest is influenced by other variables.

This study proves that the village fund allocation has no effect on poverty levels. The village fund allocation should be able to make a major contribution to the poverty level in regencies/cities in accordance with the purpose of providing Village Fund Allocation transfers, namely to support the availability of funds in meeting village expenditure (Martini, et al, 2019) needs in carrying out functions that have been decentralized and reducing poverty and reducing inequality. This means that the village fund allocation has not yet reached the goal of granting village fund allocation transfers to regencies/cities in South Sumatra Province.

This research is in line with Lalira, Nakoko, \& Rorong (2018) which states that the village fund allocation has no effect on the level of poverty. In contrast to the research results of Susilowati \& Hadi (2017), it is stated that the Village Fund Allocation has an effect on poverty. Dewi \& Irama's (2018) also state that the Village Fund Allocation has a positive and significant effect on poverty. This is due to the use of samples, and different time periods.

\subsubsection{The Effect of Village Fund and Village Funds Allocation on Poverty}

Based on the results of hypothesis testing, the effect of village funds and village fund allocation on poverty has an $\mathrm{F}_{\text {count }}$ of 19.938. When compared with $F_{\text {table }}$ of 3.14, then $F_{\text {count }}$ is smaller than the $F_{\text {table }}$ value so it can be concluded that the Village Fund and Village Fund Allocation variables together have a positive and significant relationship or effect on poverty in regencies/cities in South Sumatra Province. This means that the third hypothesis in this study is accepted. In this study also obtained a significance level of 0.000 smaller than a significance of 0.05 . This shows that the Village Fund and Village Fund Allocation have an effect on poverty. Furthermore, based on the results of the analysis of the strength of the relationship between the dependent variable and the independent variable or the analysis to find out how much the independent variable explains the dependent variable, it can be seen that the coefficient of determination $\mathrm{R}^{2}$ is 0.377 . This value means that $37.7 \%$ of the variable regarding poverty in regencies/cities in South Sumatra Province is influenced by Village Fund Allocation, while the rest is influenced by other variables.

This study proves that the dominant poverty level is influenced by the village fund and this shows that the village fund is good enough to reduce poverty in Regencies/Cities in South Sumatra Province. Meanwhile, it is necessary to use the transfer of regency/city Village Fund Allocation in South Sumatra Province to maximize the achievement of the objectives of the village fund allocation so that it has the potential to reduce poverty levels.

This research is in line with Susilowati \& Hadi (2017) and Martini, et al (2019), namely that the Village Fund and Village Fund Allocation variables affect regency/city poverty. Different from the results of research by Lalira, Nakoko, \& Rorong (2018) state that Village Funds and Village Fund Allocation have no effect on poverty in Gemeh Regency, Talaud Islands Regency. This is due to the use of samples, and different time periods.

\section{CONCLUSION}

The results of the analysis show that village fund and village fund allocation have a positive effect on poverty. The results of the partial analysis of village fund has an effect on poverty, while village fund allocation has no effect on poverty.

Further research is recommended to use more complete data with a longer study period. In addition, the variables used in future research are expected to be more complete and varied, by adding other independent variables.

\section{ACKNOWLEDGMENT}

The authors thankfully acknowledges scientific discussion with our colleagues from State Polytechnic of Sriwijaya, Indonesia. The authors would like to acknowledge the anonymous reviewers at the $4^{\text {th }}$ FIRST 2020 International Conference for their feedback on earlier version of the paper, and also thank to the two anonymous reviewers who provided feedback as part of this proceeding review process. 


\section{REFERENCES}

[1] Abidin, M. Z. (2015). Tinjauan atas Pelaksanaan Keuangan Desa dalam Mendukung Kebijakan Dana Desa. Jurnal Ekonomi dan Kebijakan Publik.

[2] Bastian, I. (2015). Akuntansi Untuk Kecamatan dan Desa. Jakarta: Penerbit Erlangga.

[3] Badan Pusat Statistik (BPS). (2018). Kabupaten Lahat Dalam Angka.

[4] Dewi, R. S., \& Irama, O. N. (2018). Pengaruh Pendapatan Desa, dan Alokasi Dana Desa terhadap Belanja Desa dan Kemiskinan. Jurnal Riset Akuntansi Multiparadigma (JRAM).

[5] Kemendesa PDTT. (2018). Anggaran Pendapatan dan Belanja Desa Tahun 2017.

[6] Lalira, D., Nakoko, A. T., \& Rorong, I. P. (2018). Pengaruh Dana Desa dan Alokasi Dana Desa terhadap Tingkat Kemiskinan di Kecamatan Gemeh Kabupaten Kepulauan Talaud. Jurnal Berkala Ilmiah Efisiensi.

[7] Martini, Rita, Agustin, Resy, \& Sari, K. R. 2020. Accrual Discretion Policy on Excess/Less Budget Financing at the Provincial Level. TEST Engineering \& Management, 82, 9925-9935.

[8] Martini, Rita, Sari, K. R., Somadi, T., \& Karman, I. W. 2019. "Financial Independence of the South Sumatra Regional Government" Proceedings of the International Conference on Applied Science and Technology 2019 - Social Sciences Track (iCASTSS 2019). 354, pp. 360364. Denpasar: Atlantis Press. HYPERLINK "https://doi.org/10.2991/icastss-19.2019.75" https://doi.org/10.2991/icastss-19.2019.75

[9] Martini, Rita, Hartati, Sukmini, Zulkifli, \& Widyastuti, Endah. 2019. Dimension of Village Expenditure in Development Sector. Advanced in Social Science, Education and Humanities Researchm the $3^{\text {rd }}$ Forum , Science, and Technology (FIRST 2019). 431, pp. 6-9. Palembang: Atlantis Press. https://doi.org/10.2991/assehr.k.200407.002)

[10] Muhi, A. H. (2011). Fenomena Pembangunan Desa. Jurnal Institut Pemerintahan Dalam Negeri.

[11] Nurman. (2015). Strategi Pembangunan Daerah. Jakarta: Rajawali Pers.

[12] Purbasari, H., Puspawati, D., Lestari, S., \& Pratiwi, K. (2017). Analisis Pendapatan Asli Desa, Dana Desa, Alokasi Dana Desa, dan Bagi Hasil Pajak dan Retribusi terhadap Belanja Modal Desa di Kabupaten Wonogiri Tahun 2017. University Research Colloquium (URECOL).
[13] Purbasari, H., Wardana, B. W., \& Pangestu, I. A. (2018). Analisis Pengaruh Pendapatan Asli Desa, Dana Desa, Alokasi Dana Desa dan Bagi Hasil Pajak dan Retribusi terhadap Belanja Desa Bidang Pekerjaan Umum dan Pertanian (Studi Empiris Di Seluruh Desa SeKabupaten Sukoharjo). University Research Colloquium (URECOL).

[14] Rahardjo, A. (2013). Pembangunan Pedesaan; Pendekatan Partisipatif, Tipologi, Strategi, Konsep Desa Pusat Pertumbuhan. Yogyakarta: Graha Ilmu.

[15] Sari, I. M., \& Abdullah, M. F. (2017). Analisis Ekonomi Kebijakan Dana Desa terhadap Kemiskinan Desa Di Kabupaten Tulungagung. Jurnal Ekonomi Pembangunan.

[16] Sari, S. P., Achyani, F., \& Cahya, B. T. (2010). Analisis Flypaper Effect pada Dana Alokasi Umum dan Pendapatan Asli Daerah terhadap Belanja Daerah pada Kabupaten/Kota di Pulau Jawa. Fakultas Ekonomi . Surakarta: Universitas Muhammadiyah Surakarta.

[17] Sekaran, U. (2011). Metode Penelitian untuk Bisnis. Jakarta: Salemba Empat.

[18] Soemardi, B. W., \& Wirahadikusumah, R. D. (2010). Kebutuhan dan Tantangan Pendidikan Infrastruktur. Bandung: Fakultas Teknik Sipil dan Lingkungan ITB.

[19] Sudarmanto, R. G. (2013). Statistik Terapan Berbasis Komputer dengan Program IBM SPSS Statistics 19. Jakarta: PT Mitra Wacana Media.

[20] Sugiyono. (2014). Metode Penelitian Pendidikan Pendekatan Kuantitatif, Kualitatif, dan R\&D. Bandung: Alfabeta.

[21] Sujarweni, V. (2015). Akuntansi Desa: Panduan Tata Kelola Keuangan Desa. Bandung: Fokus Media.

[22] Sulistiyoningtyas, L. (2017). Pengaruh Alokasi Dana Desa dan Pendapatan Asli Desa terhadap Belanja Desa di Kecamatan Baron . SimkiEconomic.

[23] Suliswanto, M. S. (2010). Pengaruh Produk Domestik Bruto (PDB) dan Indeks Pembangunan Manusia (IPM) terhadap Angka Kemiskinan di Indonesia. Jurnal Ekonomi Pembangunan.

[24] Sumpeno, W. (2011). Perencanaan Desa Terpadu (Edisi Kedua). Banda Aceh: Read.

[25] Susilowati, N. I., Susilowati, D., \& Hadi, S. (2017). Pengaruh Alokasi Dana Desa, Dana Desa, Belanja Modal, dan Produk Domestik Regional Bruto terhadap Kemiskinan Kabupaten/Kota Di Jawa Timur. Jurnal Ilmu Ekonomi. 
[26] Widjaja. (2008). Otonomi Desa: Merupakan Otonomi yang Asli, Bulat dan Utuh. Jakarta: Rajawali Pers.

[27] Yulihantini, D. T., Sukarno, H., \& Wardayati, S. M. (2018). Pengaruh Belanja Modal dan Alokasi Dana Desa terhadap Kemandirian dan Kinerja Keuangan Desa di Kabupaten Jember. Jurnal Bisnis dan Manajemen (BISMA).

[28] Zulkarnaen, \& Saebani. (2012). Hukum Konstitusi. Bandung: CV Pustaka Setia.

[29] Republik Indonesia, Undang-Undang No. 6 Tahun 2014 tentang Desa.

[30] Republik Indonesia, Undang-Undang No. 28 Tahun 2009 tentang Pajak Daerah dan Retribusi Daerah.
[31] Republik Indonesia, Peraturan Pemerintah No. 43 Tahun 2014 tentang Pajak Daerah dan Retribusi Daerah.

[32] Republik Indonesia, Peraturan Menteri Dalam Negeri No. 113 Tahun 2014 tentang Pengelolaan Keuangan Desa.

[33] Republik Indonesia, Peraturan Menteri Dalam Negeri No. 20 Tahun 2018 tentang Pengelolaan Keuangan Desa.

[34] Republik Indonesia, Peraturan Menteri Desa, Pembangunan Daerah Tertinggal, Dan Transmigrasi No. 19 Tahun 2017 tentang Penetapan Prioritas Penggunaan Dana Desa Tahun 2018.

[35] Republik Indonesia, Peraturan Menteri Desa, Pembangunan Daerah Tertinggal, Dan Transmigrasi No. 3 Tahun 2015 tentang Pendampingan Desa. 